\title{
Perspective
}

PERSPECTIVE Actualité en histoire de l'art

\section{2| 2014}

\section{Antiquité/Moyen Âge}

\section{Questions on "world art history"}

Questions autour de l'" histoire mondiale de l'art"

Zainab Bahrani, Jas Elsner, Wu Hung, Rosemary Joyce and Jeremy Tanner

\section{(2) OpenEdition}

\section{Journals}

\section{Electronic version}

URL: http://journals.openedition.org/perspective/5587

DOI: $10.4000 /$ perspective. 5587

ISSN: 2269-7721

\section{Publisher}

Institut national d'histoire de l'art

\section{Printed version}

Date of publication: 1 December 2014

Number of pages: 181-194

ISSN: 1777-7852

\section{Electronic reference}

Zainab Bahrani, Jas Elsner, Wu Hung, Rosemary Joyce and Jeremy Tanner, «Questions on "world art history" », Perspective [Online], 2 | 2014, Online since 30 June 2016, connection on 01 October 2020 URL : http://journals.openedition.org/perspective/5587 ; DOI : https://doi.org/10.4000/perspective. 5587 


\title{
Questions on "world art history"
}

\author{
A discussion between Zainab Bahrani, Jaś Elsner and Rosemary Joyce \\ moderated by Jeremy Tanner, with a comment by Wu Hung
}

The choice of this theme for debate has been stimulated by recent discussions of the globalization of art history, and the increasing emphasis placed in the discipline on the notion of "world art history," perhaps best exemplified by the books of James Elkins and David Summers: James Elkins, Is Art History Global? and David Summers, Real Spaces: World Art History and the Rise of Western Modernism. ${ }^{1}$ Most of the discussion has focused on Renaissance and later art, but the purpose of this debate is to reflect on the relevance of these debates in particular in relation to the art of "ancient worlds."

Jeremy Tanner. What do you regard as the major factors that lie behind the rise of "world art history," and what factors would you see as driving developing patterns of interest in world art history today and in the next decade or two? What would you see as the relationship between world art history and broader social-cultural transformations such as "globalization"?

Jaś Elsner. When I began in the game of art history (my first junior job was at the Courtauld Institute in 1991), the subject, as taught in Europe and America, was largely about Western art. In many ways it was a cultural apologetics for European culture and education, presented as the canonical selection of the noblest masterpieces in the visual field, with after the 1980s an edge of cultural critique (sexuality politics, ideological analysis, deconstruction, postcolonialism) among the young, that could be vicious and polarizing in relation to the older generation. This has changed. The impact of globalization on the discipline - not only a vastly more interconnected world as well as the rise of the Far East (China, Japan, Korea), the Indian subcontinent and Latin America as major economic forces, but also the political pressures of crisis in central Asia, the Middle East, Africa, and Eastern Europe and the Balkans - has gone hand in hand with the rise of world art history, especially in the United States. What this means institutionally is not a unified field or a single discipline, but the pressure of educated ethnic groups in the US demanding and receiving a voice for the arts of their ancestral cultures within the university system - Chinese, Indian, Afro-American, African, Meso-American, Iranian, Jewish and so forth. This has led to a wholesale reinvention of the discipline in the country of its strongest professional presence and its largest body of teachers, researchers and students. Instead of having an expert in every century of European and North American art, the numbers in these traditional fields went down and posts went instead to the variety of areas of world art (meaning essentially non-European). The old "art history survey" - a venerable form of lecture series that focused chronologically almost entirely on Western art - was scrapped in favor of all kinds of methodological, historiographic, theoretical and multicultural experiments.
Zainab Bahrani is the Edith Porada Professor of Art History and Archaeology at Columbia University in New York. Her most recent book is The Infinite Image: Art, Time and the Aesthetic Dimension in Antiquity (London, 2014).

Jaś Elsner, Humfry Payne Senior Research Fellow in

Classical Archaeology at Corpus Christi College Oxford and Professor of Late Antique Art, most recently published Art and Rhetoric in Roman Culture, edited with Michel Meyer (Cambridge, 2014).

Wu Hung is Harrie A. Vanderstappen Distinguished Service Professor in Chinese Art History and Director of the Center for the Art of East Asia at the University of Chicago, and author of numerous publications on traditional and contemporary Chinese art.

Rosemary Joyce is Professor of Anthropology at the University of California, Berkeley. Since 1977, she has conducted archaeological fieldwork in Honduras and museum research on collections from Central America in museums in the Americas and Europe.

Jeremy Tanner, Professor of Classical and Comparative Art at the Institute of Archaeology, University College London, is currently undertaking a comparative study of art in classical Greece and early imperial China. 
The old model was farcical: when Michael Hirst - a distinguished sixteenth-century Italian expert - retired from the Courtauld in the late 1990s, his colleague Jennifer Fletcher - also an eminent expert on Italy who taught the seventeenth century - insisted that she replace him and never teach the seventeenth century again. So a replacement was hired for her, in seventeenth-century Italian art. But there were positives in the old system: narrow specialization focused by a strongly historicist framework brought indepth linguistic and cultural command within a specific field of study so that art history could be integrated within all other cultural phenomena. Now, with posts normatively specifying huge scholarly arenas (the arts of all Europe north and south from 1600-1900, for instance, or the arts of Europe 1400-1700) no teacher can have the depth of expertise or the breadth of specific command - material and linguistic - that was true even a generation ago. Moreover, in the past, when art history was seen as a narrowly Western discipline, there was indeed the potential for a broad cultural dialogue among scholars and students within a department: all worked on different aspects and moments in the unfolding Western tradition (a model of art history associated with all the field's founding fathers from Giorgio Vasari and Johann Joachim Winckelmann via Heinrich Wölfflin and Alois Riegl to Erwin Panofsky and Ernst Gombrich).

That dialogue has been shattered. Today, art history departments consist of small groups - Asianists, Africanists, Meso-Americanists, Medievalists, Ancients, Early Moderns and Modern Europeans - who have little in common in terms of their historical, conceptual or theoretical interests and little knowledge of the cultures or languages with which each group may work: effectively a balkanization into numerous virtually independent sub-departments. And all are in fact defensively aligned against the overwhelming desire and urgency for contemporary art among the student body, which is now the one universal factor in the field! The result of all these subfields is the move (apparent everywhere except in European art) for a kind of area-studies specialism where scholars work on all periods from ancient to contemporary. This is in itself probably a good thing, but - in its further destabilization of a strong historical basis for thinking about works of art in their deep cultural contexts of making and reception - it contributes to an increasing loss of a sense of cultural specificity and historical particularity in both younger researchers and many students. Moreover, the generalization of the field into large arenas of expertise has still further squeezed those aspects that have historically been less popular: notably architecture and sculpture have virtually vanished to make way for painting, photography and all that is flat.

Rosemary Joyce. "World art history" reflects the discipline of art history grappling with histories of coloniality, trying to define a way to be part of a new, broader world landscape in which art histories might come from places other than Europe and North America. David Summers' discussions of Teotihuacan and the Mexica Coatlicue suggest that world art history can comprehend fundamentally different traditions in something like their own terms. ${ }^{2}$ James Elkins vacillates between acknowledging that art history is no longer a provincial practice and inscribing an enduring difference between art history and appreciations of the same works that might reflect other epistemological positions. ${ }^{3}$

Debates about world art history can seem at times very much insider conversations, having little to do with other disciplines. This is especially true when world art history is understood to project a future in which once parallel and independent histories of art (David Carrier's monocultures of European, Islamic, Indian and Chinese art, for example ${ }^{4}$ ) will be thoroughly entangled in a globalized contemporary art. 
At times, it is acknowledged that these histories already have been entangled for perhaps their entire existence, even as the term "global" is reserved for the present and future. Monica Juneja is particularly sharp about the potential for world art history to slip into a "conceptual imperialism" that she thinks might be avoided by "global art history."

One way concepts of global and world art histories could develop in the coming decades might be by confronting the only art that can be safely said to have arisen independently of Europe: the art of the Americas prior to colonization. Engagement with the Americas could allow consideration of the utility of concepts developed in the history of European art, like portraiture, for understanding objects like the small-scale, handmodeled fired clay sculptures of human figures, made between 900 and 500 BC in Honduras, one of the foci of my research (fig. 1). I find Summers' concept of facture useful in thinking about these, as indexicality (with which he equates facture) can be traced even when, as in this case, no textual tradition survives from the makers of these works. Yet world art history is not indispensable to such a project; the utility of a comparative approach to portraiture has been demonstrated by Jeremy Tanner and is endorsed in a recent summary of the more interdisciplinary field of world art studies. ${ }^{6}$

Zainab Bahrani. World art history may be on the rise, but at the moment it is limited to a few institutions, mostly in the Anglophone world. There is a difference between art histories practiced in the United States and Canada and those practiced in the United Kingdom and in continental Europe, so one can not speak of a unified western art-historical practice today. In German language scholarship, the stress on images as media has taken art history in a different direction, for example. I will not discuss the art histories practiced in other parts of the world, as those would require asking a different set of questions about classifications of arts and relationships with the past in the area of ancient art.

In North America, where introductory grand surveys of history and of art history have long been standard at most of the large universities, the turn to world history was originally a pragmatic step in the configuration of the curriculum. The interest in world art history that followed was not a decision resulting out of any epistemological questioning of the field's character. The heterogeneity of the population meant that including non-European histories became a necessity, as North America has a different attitude to what in Europe are sometimes called autochthonous and allochthonous citizens. By the early 1990s it became clear that teaching European history as if it were world history could no longer work in the American university. At the same time, art history increasingly turned to the idea of world art within the art history survey and its textbooks. This change was less successful than the changes instigated by the discipline of history. Whereas the aim of the latter was to understand world history as a decentered narrative, no longer positioning Europe as the linchpin of historical development across the globe, in art history, world art studies, or the global art survey, the field continued to place Europe and North America as the center of art-historical surveys, or perhaps rather it is better to say that it placed art at the center of Europe (fig. 2). That is to say the notion of "art," or the category of "art" that the discipline had at its basis, remained the European one, and others were compared to it and found adequate or wanting. This step, often derided as "the West and the rest," was the equivalent to what in feminist theory we call "add women and stir," the approach that meant we leave the androcentric historical structure intact 


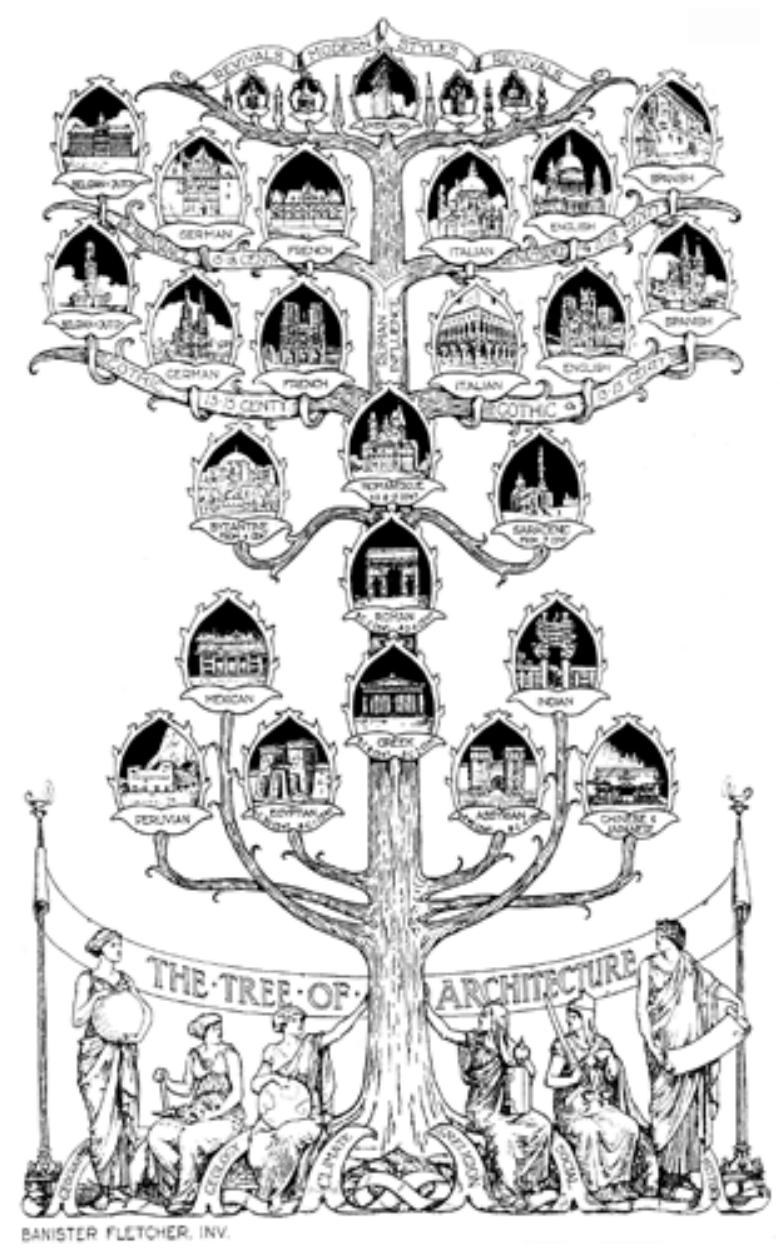

but simply throw a few women into the mix. It does not question at the epistemological level anything at all and is in fact even more worrying because it further reifies and normalizes European academic definitions.

Whereas some scholars in the 1990s and early 2000s had made the attempt to think of world art as an epistemologically different enterprise than simply adding a few other cultures at the side of the standard Eurocentric narrative, these scholars were few and far between, and their work has not had much of an impact on the field as a whole. Many of those who work in the Western tradition have simply found it unnecessary to engage with these critiques. Perhaps more worrying are declarations of Western uniqueness, such as Elkins' assessment that all art historians use Western scholarly methods, namely archival research, and referencing systems. ${ }^{7}$ Craig Clunas has countered this remark brilliantly by stating that this is akin to saying that "the US Marine Corps is 'Eastern' because explosives are central to its mode of operation" ${ }^{8}$ I can only add to Clunas's remarks by pointing out that if we are to think along the lines that Elkins has set for us, we might equally declare that all western scholarship is fundamentally Mesopotamian because writing, archives and written scholarly inquiry itself are all ancient Mesopotamian inventions.

As this short questionnaire is not a place for a literature review, I will only point out that, in many ways, world art studies seems simply to revive the Hegelian inspired universal history and aesthetics of the nineteenth century, the difference being that while trying to

2. Banister Fletcher, "Tree of Architecture," in Banister Fletcher, A History of Architecture, London/ New York, (1896) 1950. do away with a teleological tale of progress of civilization that utilized the ancient and the non-European as the first malformed steps towards the fully formed aesthetic sensibility of the modern West, it makes a small change. In world art studies, the teleology of progress that subsumed other cultures into one unilinear explanatory frame is displaced by a comparative mode that nevertheless privileges western European art from post-Renaissance modernity and later. Let me repeat again what I have published before on several occasions: right from the start, the discipline of art history did not so much exclude as disavow the world of art outside Europe in a continuous reiteration of its own terms. These terms became (and continue to be) a tautological means of maintaining art history's own definitions.

How is this turn to world art history related to globalization? Even in the field of contemporary global art, this issue is often left woefully under-theorized. Of course, globalization is not an all-inclusive model that we ought to aspire to in academic research. In post-Marxist terms, one of its art-historical manifestations might be seen in the current interest in the work of art as a commodity with the focus on circulation and exchange, of political power and economic value rather than on other aspects of the study of the visual arts or aesthetic practices. World art history is certainly not the reflection at the level of the curriculum of a wider international interaction at the economic level. 
Jeremy Tanner. How far do you see the recent rise of interest in "world art history" as representing a major change in the character of the disciplines of art history and archaeology? Would you see those changes as more epistemic (ways of writing and thinking about art), or organizational (the range of traditions taught in art history and archaeology programs, global patterns of art collecting and museum display), and how would you see those changes to be related?

Zainab Bahrani. The changes in art history that have led to world art studies certainly were not the epistemic shift of the New Art History of the late 1970s and 1980s when the field became far more self-reflexive and philosophical, far more interested in theoretical bases of forms of knowledge and the historical context of their production. It is promising now that the new directions of post-humanism and object ontologies, the reinvigor-

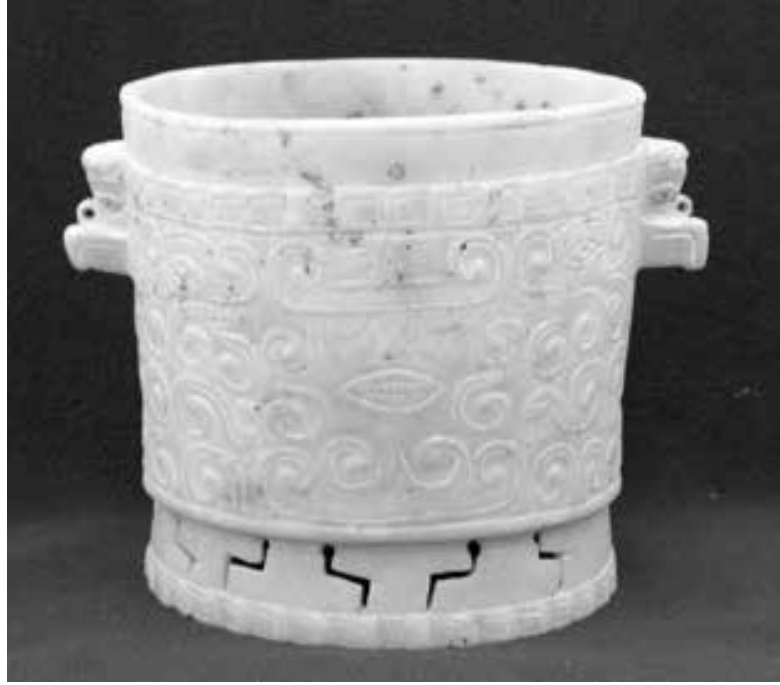

3. Ulua marble vase, Río Ulúa valley (Honduras), AD 650-850,

Washington, D.C., National Museum of the American Indian, Smithsonian Institution (6/1262)

Rosemary Joyce. Archaeologists working on the Americas have not been shy about proposing interpretations of ancient art worlds using art historical concepts. For example, between AD 600 and 1000 in the Ulua valley of Honduras, an indigenous tradition of carving marble vases developed (fig. 3). The major modern study placing these objects in a historical context, as products of specific workshops linked in a tradition over time, with patrons for whom they constituted high art, explicitly builds on George Kubler's The Shape of Time. ${ }^{9}$

Archaeologists may still worry about deploying a concept of "art" that may be alien to the people whose works we narrate. In the Americas, the same concern is expressed by leading art historians, including Carolyn Dean. ${ }^{10}$ Of course, it has been argued in recent years that Precolumbian art history is out of step with broader art history. This could account for my not noting a great difference between how my colleagues trained in art history and I approach our common subject matter. ${ }^{11}$

In particular, I look at world art history from the perspective of a scholar working at the geographic interface between the world of the Classic Maya and little-known traditions of Central America. I cannot really discern any significant recent changes in collection, display or what constitutes significant works from the Americas that must be incorporated in teaching. For Central America, this question was settled a century (or more) ago, as museums and departments of art history identified a canon of Precolumbian art worthy of study. Honduran Ulua marble vases became recognized art by the 1920s, as museums in the United States and Great Britain bought, published and exhibited examples. Eliminated from display in the same museums was a closely related group of stone vessels from the northeast coast of Honduras, some of which actually were among the earliest works from Central America on view in institutions like the British Museum in the eighteenth century (fig. 4). ${ }^{12}$

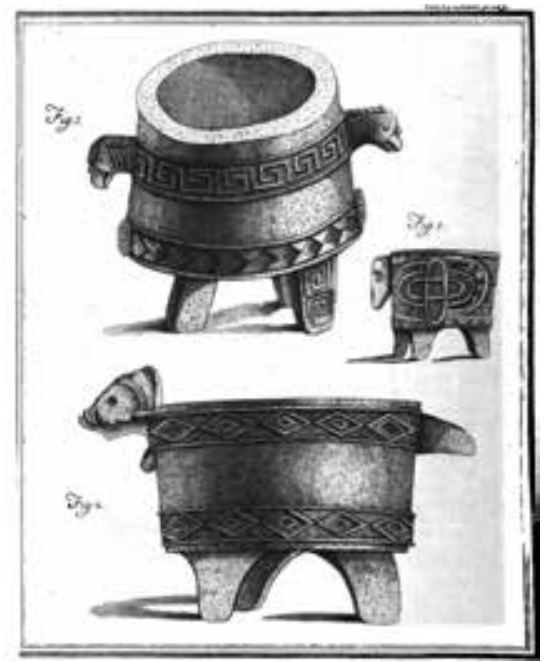


Hence, I lean towards seeing concerns with the diversity of issues framed as "world art history" as attributable to epistemic change. In particular, it appears that art history has rediscovered a need to be universal in truth, to be able to provide greater understanding of art worlds even when these are not part of European history.

Jaś Elsner. The fundamental epistemic change in the shift to world art is the death of history. I mean by this the move towards easy postmodernism and surface semiotics from a close-focused, culturally and socially integrated approach to the causes and effects of the making and experience of works of art in their time of creation and their later reception. ${ }^{13}$ This is not merely a disciplinary problem for art history but affects most of postmodern culture, and it means that instilling a deep historical grasp of how objects may develop within specific cultural constraints is now a genuinely uphill struggle by comparison with earlier times. Organizational change - necessary in relation to epistemic change - must inevitably follow: but the problem is what we want to teach and how much we can teach within a limited time-frame.

Jeremy Tanner. To what extent does the rise of world art history require changes in the ways in which students and researchers are trained, in particular in the context of graduate programs in art history and archaeology? What relationship, if any, might "comparative art" have to "world art"?

Zainab Bahrani. The way that art history is taught will no doubt continue to depend on local factors, but a world art history approach might mean that critical reflection on the field's structure and terminology, as well as on the position of the art historian as a cultural translator who ought to be aware of ethnographic critiques, can now be addressed in introductory lectures. As world art history has opened up a debate that has permitted the questioning of standard discourses and institutional practices of art, it can be a productive new direction for teaching.

Rosemary Joyce. World art history would seem to require that anyone who wants to attempt to understand the art of any world region must be prepared to engage with the art of other areas as well. That is, if your goal is to deploy concepts developed through understanding European art - even transformed concepts, like those championed by Summers - in studies of arts of historically independent areas (the extreme case being the Americas), then you had better be able to do a competent job with those tools in their classic setting of European art history.

This is what I find intriguing about world art history as a potential way to approach works from the early Americas. Esther Pasztory made an argument for interrogating the European art-historical concept of "naturalism" through study of Olmec and Moche art. ${ }^{14}$ Summers' concept of "spatial arts" might be critically examined through Carolyn Dean's radical attention to Inka rock outcrops that may be worked, unworked and framed, or simply recognized without apparent physical marking or framing. ${ }^{15}$

I see this as quite distinct from a "comparative art" project. At its worst, comparative art arrays unrelated things that can be argued to be examples of what Summers would call a specific format, and from that format attempts to make sense of all of them. A good example is the recurrent attempt to understand early figurines in the Americas by abstracting them from their contextual situations (and thus from their histories) because they all show human figures at small scale. Such comparative studies happily attempt to account for figurines made within the 
last two millennia in Central America by relation to European Palaeolithic figurines of much earlier date, ignoring how the social relations within which the former were made in agricultural villages differ from the social relations of Palaeolithic hunting and gathering peoples of mobile habits.

I would much rather turn to my corpus of figurines armed with a conceptual understanding of the range of ways in which portraits were made in the European tradition, the degree to which physical distinction was necessary for something to be recognized as an image of some particular person, and questions about how a portrait can work as an index of a person.

Jaś Elsner. My own view is that world art history - if we mean some kind of universalist conflation - is not a real field and will go nowhere. Comparative art history, on the other hand, is an essential process in the new environment, since it is the only opportunity for the different specialist sub-departments of students and scholars within art history to begin a creative dialogue between and among each other. But the problems are vast. First, there is no single egalitarian field of art history. The discipline was born out of European apologetics, and its every reflex is deeply redolent of the intellectual structures created especially in Germany after the Reformation and above all in the nineteenth and twentieth centuries. This means it bears the heavy scars of profoundly ideological positions and a good deal of obnoxious politics - not least a fundamental racism, as well as Eurocentrism, an overweening sexism, as well as hegemonic attitudes about sexuality - which are not easy reflexes about which to be self-conscious, let alone from which to be free.

If we think about other cultures, there is no art history of the ancient literate civilizations (e.g. China, Japan, India, Islam) that is written from their internal intellectual perspectives. All approaches - whether in the work of Western or indigenous scholars are dependent on the German-American tradition as it developed from Winckelmann to Panofsky and on the post-structuralist New Art-Historical response. Eurocentrism in this discipline is inevitably and fundamentally promulgated, even as and when it is most vigorously denied. In oral cultures - the art history of Australasia or many parts of Africa, say - the situation is still worse since we have very little by way of ancient testimony, or conceptual models for dealing with orality, and are fundamentally dependent either on the imposition of modern, Western-generated theory or on very limited and recent anthropological information with all the problems of the ethnographer's (often unconscious) interpretative intervention in his or her account. Nor is the scholarly basis of the diverse fields remotely parallel. Classical Greek and Roman art history developed a comprehensive corpus of relevant ancient texts about the range of relevant ancient objects, their social contexts and the ways they can be viewed, as early as the mid nineteenth century, and this has been periodically updated and translated into all the languages that students need. The same has been done for most areas of European art, including Byzantium, through the twentieth century. Nothing like this exists or has even been attempted for such venerable fields as Islamic, Indian or Chinese art - although the wealth of material is vast. Many texts (especially on the Hindu and Buddhist side for instance) have hardly been edited, and certainly not translated, let alone excerpted to allow collection in some kind of art-historically useful handbook.

In other words, what I am saying is that before we can even attempt some kind of comparative model of approach we have to recognize (and ideally - over the next generation - do something about) the totally uneven basis of our scholarly starting points in relation to the cultures and arts we want to compare. 
Jeremy Tanner. How far do you see the significance of the rise and impact of world art history as having specific importance for the historians of the arts of "ancient worlds" as opposed to the art of more recent periods?

Rosemary Joyce. I find three things attractive about world art history when I turn to the ancient Americas. The first, paradoxically, is what Shelly Errington found most problematic, in her commentary on Elkins's Is Art History Global?: the employment of the term "art." As an anthropologically-trained archaeologist, I was taught that the people I study cannot be assumed to have "art." Allowance being made for them to have "visual culture" let me continue my work, but since I have grave reservations about the utility of the word "culture," the aggregate "visual culture" soon became "visuality." 16

This has always bothered me, because my interest has consistently included questions of the way that making, not just viewing, produced specific subjectivities. I have always been interested in the position taken up by the makers of ancient Honduran figurines, who crafted fine detail barely visible unless one holds, rotates, and closely examines these things. The mastery of the material, the observational and conventionalizing moves, and the moments of innovation have invariably seemed to me to be the most interesting things about these works. By ruling them out along with the word "art," my discipline impeded my attention to them, until the adoption of concepts of "communities of practice" and "technological style" gave me an alternative vocabulary. Yet it did not admit what I would assert: these things were art.

At the same time, most traditional approaches from art history, especially those preferred in Precolumbian art history, present particular difficulties for me. Even for the more recent period when Ulua marble vases were carved, we have no surviving texts from Honduras. Their makers probably spoke a language no longer in use, and what little was recorded before the language fell into disuse were texts rooted in the much later colonial period. World art history, especially as advocated by Summers, provides a set of concepts that do not rest on access to texts, making my work viable as a contribution to a history of ancient art of the Americas.

The final thing I find attractive in world art history is the sometimes ambiguous commitment to a non-progressive, though still historical, approach. That this might allow appreciation of works and their histories that did not meet the aesthetic criteria of European and North American scholars and museums is the (as yet unfulfilled) promise that makes world art history interesting to pursue for a history of art that developed without influence from or knowledge of Europe.

Jaś Elsner. I think classical art and archaeology has remained too locked into its own narrow world of European ancestry. Of course it is the deep dynamic of wanting to understand the underpinnings of European culture that is the driver for the interest in classics in the first place. But there is a real need to branch out into comparative work with the sister antiquities - Egypt, Mesopotamia - and beyond those into a kind of comparativism with other ancient artistic cultures such as China or India. ${ }^{17}$ But for individual researchers to do this is a huge demand (above all in language learning), and very few have been able to manage (the moderator of this debate being a very rare exception!). I think what is needed is a new model of collaborative working between groups of scholars across the ancient fields. We have much in common, not least a mutual epistemological understanding of ancient material culture through surviving texts, through archaeology and through the very fragmentary remains of a small percentage of the totality of the past as our only way into making 
a coherent vision of its reality. This is in contrast with the much vaster percentage of what can be known in the modern and contemporary fields (meaning that no scholar can command the empirical knowledge base of a whole field, as he or she can in ancient art). It is also in contrast with the archaeology of non-literate societies (such Paleolithic or Neolithic) since we can supply some textually-derived information from antiquity to help us with our understandings as opposed to needing to rely entirely on modern theory to inform the material-cultural finds.

Zainab Bahrani. In the United States, ancient art is part of art history departments. However, this is not the case in much of the rest of the western world, where art history begins in the European Middle Ages or with the Italian Renaissance. Yet ancient art is paradoxically not excluded from art history. In the early days of the discipline, classical antiquity and even ancient Near Eastern and Egyptian arts were taken up and subsumed into narratives of art and aesthetics. Even Vasari refers to Chaldean and Egyptian art, and Winckelmann dedicates a large section of his comparative art history to the ancient Near East. These areas of antiquity were necessary for the construction of the European self by means of comparison to the other in the teleological narrative of universal histories such as Hegel's and especially in his Aesthetics. What needs to be addressed is how this inheritance still plays out in the way that we study and teach ancient art today. In other words, the new interest in World Art has not changed the position of ancient art in the field of art history. Within ancient art itself, however, the great wall between the field of Classics and that of ancient Near East and Egypt, for example, has begun to be demolished in recent years, and thematic collaborative and comparative studies of ancient art, ritual, divine images and so on are being produced that cover cultures that are not always historically or geographically related but are considered together in a comparative frame as "the ancient world."

In fact, I wonder if the question should not have been asked the other way around. How has the study of ancient art and the work of ancient art historians and archaeologists impacted this shift? What can the study of ancient art and art worlds contribute, and why are scholars of later periods less well informed about ancient art worlds and concepts of art and aesthetics? Image studies and visual cultural studies seem to solve problems by focusing on images and visual media. These approaches include ancient art in their comparative discussions, but they continue to privilege modern Western notions as normative concepts of representation and visual logic. They are also often historically erroneous in their references to pre-modern eras and the arts of the world beyond the limits of Western Europe. In terms of antiquity, for example, recent books in image studies imply or state that the earliest written evidence for art and images before Greece and Rome is to be found in the Bible. This is what I would call the creationist model of art history. As with religious creationism, it depends not on scholarly research and scientific evidence but on blind belief.

Jeremy Tanner. How far, and in what ways, do you see the rise of world art history as affecting your own practice as an art historian/archaeologist?

Rosemary Joyce. While I am intrigued by the potential to contribute to an understanding of art that was not part of any extended European sphere, without subordinating it to a conceptual location as primitive "other," I find the insistence in much of world art history on the definition of art history as a discipline makes it unclear how I might engage with this work. This is of course a stronger theme for Elkins than for Summers, but it is there in both bodies of work. 
5. Alfred Hamilton Barr, Jr., cover of the exhibition catalogue Cubism and Abstract Art, Museum of Modern Art (MoMA), New York, 1936, The Museum of Modern Art Library, New York, MA143.

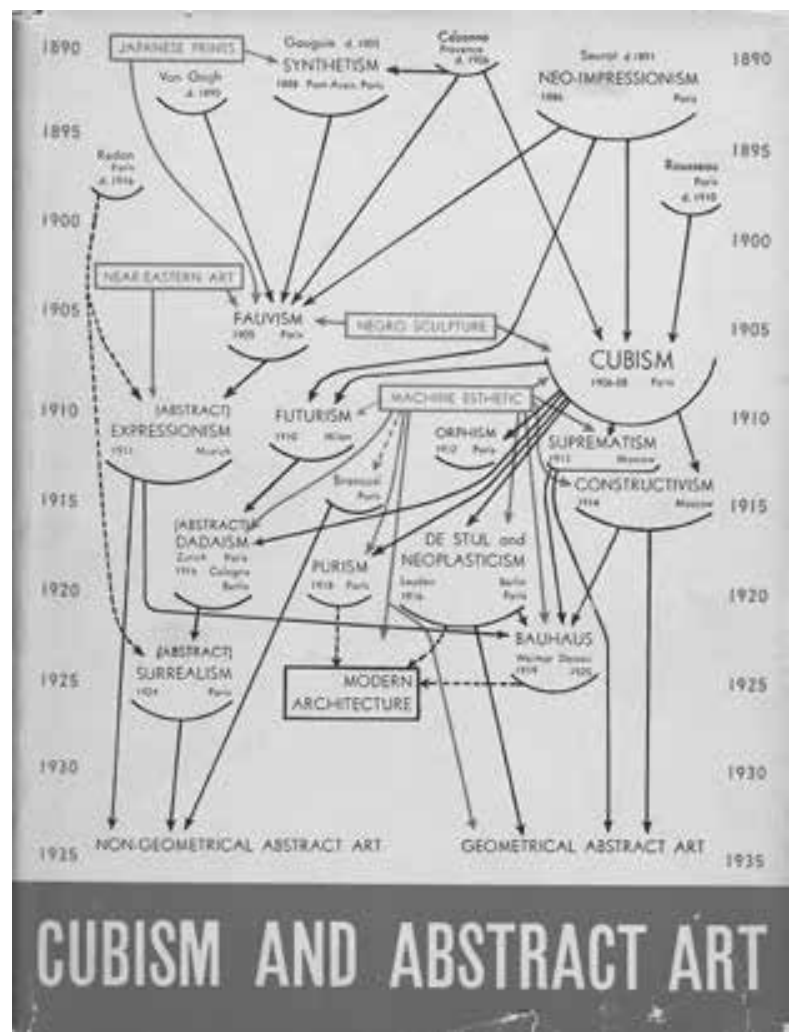

Because I have long been interested in thinking about the making of images, not just their formal patterning or iconographic content, and have employed Peircean concepts of indexicality in the study of Honduran figurines, I find Summers's discussion of facture especially interesting. In my view, however, to truly understand facture requires an immersion in the local context that is absent from the few world art history commentaries on Precolumbian art of the Americas to date. This has convinced me, as it has many of my art-historical colleagues, that what we need is an approach that considers indigenous concepts. ${ }^{18}$

This is precisely where there is tension in writing about world art history, especially from Elkins. I am ready to talk about ancient Honduran figurines as art; but first, I want to understand them as part of flows of clay, as extended parts of the bodies of their makers or users, as simultaneously sculptures and (at times) pendants or (at other times) bottles. I don't see much space for these interests in debates about world art history within the discipline of art history.

I think related concerns are the reason there is really so little work by archaeologists explicitly engaging with world art history. In a recent issue of World Art presenting work by archaeologists (including archaeologists of the ancient Americas), the only mentions of world art history, and the only citations of its key works, were in the framing foreword and afterword by the journal's editors. The individual authors drew explicitly on a wide range of theoretical resources in anthropology, archaeology and traditional art history. The contemporary theory with which these authors engaged came from the interdisciplinary discussion of materiality, within which objects that could be viewed as "art" can be easily subsumed. The question is what we lose by treating these works only as objects through the lens of materiality theories, and what might be gained by viewing them as part of world art history. ${ }^{19}$

Zainab Bahrani. I have felt a need to address the larger interpretive framing of the universal art history and the place of ancient Near Eastern art within it since my earliest publications. I have described this as the enunciation of cultural difference that re-inscribes alterity. ${ }^{20}$ In my 2003 book The Graven Image, I addressed this issue extensively in a chapter called "The Aesthetic and the Epistemic: Race, Culture and Art History" and in another chapter, "Ethnography and Mimesis: Representing Aesthetic Culture" ${ }^{21}$ The reason that I refer to these early works here is to point out that as a scholar of ancient Near Eastern art, to do art history has meant to tackle an interpretive frame and an epistemological logic that even now continues to uphold a hierarchy of world cultures (fig. 5). World art history or global art history can either posit universal laws that regulate the progress of art, or categorize cultures comparatively but separately as if they were isolated units. In order to move beyond these constraints I have worked in the postmodern and post-Marxist critical traditions of discourse analysis and philosophical reflection on such things as ontologies of images, relationships between concepts of 
representation and reality in ancient thought, and how to think outside the constraints of mimesis (fig. 6). Yet it is important to stress that any theoretical or comparative approaches are doomed to fail without a strong historical grounding in the ancient languages and scripts, and archaeological and textual contexts, areas of scholarship that are regrettably being left behind. A comparative world art history is perhaps best approached as a collaborative project, as this discussion has shown.

Jaś Elsner. I will be personal here. I have attempted to rise to the challenge of comparative art history within the specific field of late antique art, on which I mainly work, in two specific contexts. First, as a member of the Center for Global Ancient Art at the University of Chicago, I have collaborated in dialogues with scholars in ancient fields that have no juncture of influence or connection. Here the comparators must be rigorously methodological and indeed in some respects formal. The Center contains three historians of ancient European art (Patrick Crowley, Richard Neer and myself) whose objects of interest are obviously connected. But our dialogue is with experts in ancient China (Wu Hung) and ancient Meso-America (Claudia Brittenham). What we share is literate cultures with various forms of writing (inscriptions and written texts) from which some kind of cultural framework can be developed to put against objects whose artifactual reality (from our modern epistemological perspective) is dependent on archaeological excavation; the fact that in absolute chronological

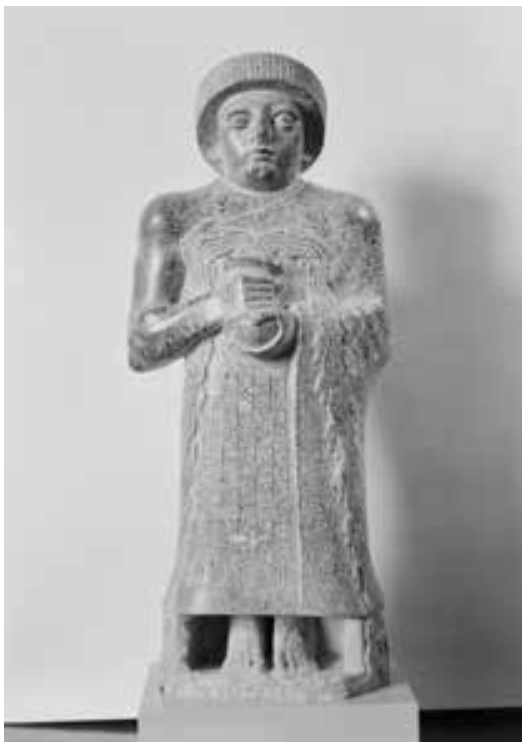
terms an Aztec object may be from AD 1400 is much less important than that it has been dug up from the earth in modernity, like a Roman statue, and needs to be understood in a cultural context pieced together from fragments of evidence which comprise a small percentage of the totality of what once existed (like any object of Greek or Han Chinese archaeology, for example). In taking conceptual categories of kinds of objects that appear in all these cultures (for instance figurines or vessels) or ways of relating to objects (for instance cases where they were made to be invisible or hidden), we can compare deep and culturally-situated readings of chosen objects or groups in order to see how - to take one example - vessels in Greece, Mexico and China may throw light on differences of usage and different kinds of relations to the body of users. The result has been a vibrant process of revelation for all concerned - both in thinking through the material-cultural semiotics of objects and in creating an active dialogue across some of the ancient disciplines that sit in a typical world art history department. ${ }^{22}$

Second, as Principal Investigator of the Empires of Faith project at the British Museum and in Oxford, I have been developing a model - with a group of eight other scholars - for thinking about the changes in the art of late antiquity and the rise of distinctive iconographies in the religions of the time, many of which have survived as today's world religions. Here we deal with cultures that were in contact and whose visual systems developed in part through knowledge of each other and in part through structural differentiation. But we deal also with a heady moment of modern ideological investment - since nothing is so polemicized, ancestral and ideologically charged as religion (to the adherents of various faiths, to their various enemies and to secularists who have tended to detest any and all religions). Part of the problem in this project lies in grasping and rejecting historiographic assumptions and truths, whose principal basis is prejudice, exceptionalism or self-justification by means of alterity, and then - still more daunting - to try to put in place the basic elements of a method that might do better and offer the chances for a comparative analysis. 
7. View of the Giza Pyramids, Egypt.

8. A Shang Dynasty bronze fang yi vessel, twelfth century BC, Washington, D.C., Arthur M. Sackler Gallery.

\section{Comment}

\section{by Wu Hung}

Among the new historical conditions, two frequently cited are the drive toward multiculturalism in education and the growth of contemporary art into a globally connected field of study. A less mentioned but imperative new condition, however, is that participants in the current discussion are no longer limited to scholars trained in European art but include historians working on various non-Western art traditions. The collective knowledge, perspectives and experiences they bring into the discussion will help overcome an old but persistent assumption: namely, that a single mind can invent a theoretical or historical scheme to encompass the art of all times and peoples. Guided by this assumption, several authors have written monumental books of world art history, whose main significance actually lies in advancing particular points of view.

Before engaging in a debate about "world art history," it is crucial to recognize that this idea is not new. The birth of the encyclopaedic museum, which aspires to gather art objects all around the world under one roof, already implies such a historical construction. In scholarship, as Ulrich Pfisterer and others have shown, a specific constellation of anthropology, psychology and evolutionary theory gave way to "a consideration of all the products or art worldwide" around 1900 in Germany. ${ }^{23}$ A recognition of these precedents is important because it focuses our attention to new historical conditions in thinking about world art history, and cautions us against repeating old assumptions and arguments.

I would suggest that world art history should be broadly conceptualized as an unfolding dimension of art-historical scholarship. As such, it will inspire a multitude of research projects as well as diverse research methods. It will not replace the existing art history, which is basically a conglomeration of regional and national art histories, but will complement, problematize and reorganize it. The result will be a new, three-dimensional structure, in which multi-linear, "vertical" national art histories are connected into layered, "horizontal" world art histories. ("Global ancient art" and
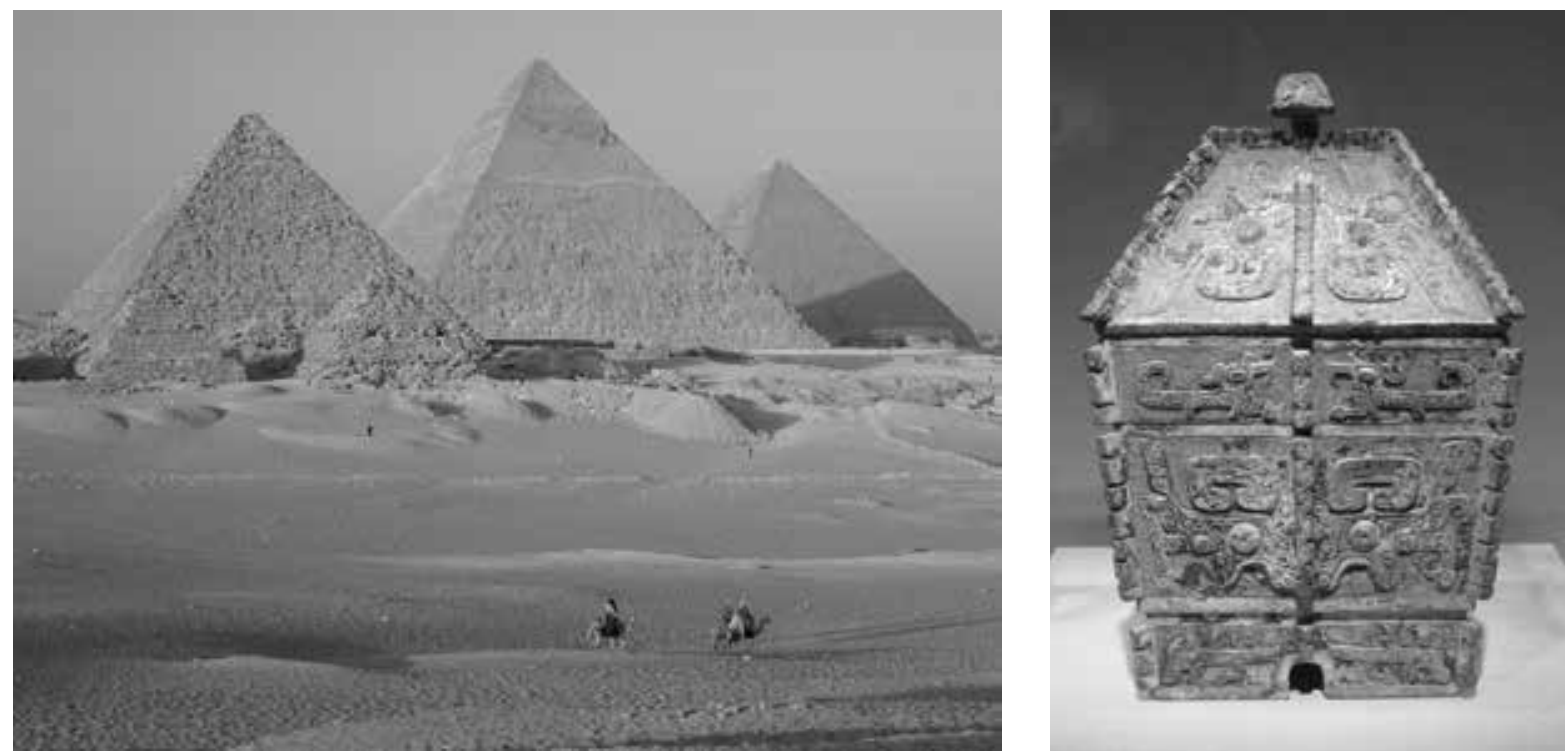
"global contemporary art" are just two examples of such world art histories.) This threedimensional art-historical knowledge will further reshape art-historical institutions, including academic departments, research institutes and museums. In this sense, the development of world art history is both epistemic and organizational. It is not an addon to knowledge, but is rooted in the development of the discipline of art history itself.

To develop narratives of Chinese art in a conceptual or historical global framework has been a purpose of my own writing, as evinced by my works on monumentality in ancient art, the trans-regional spread of Buddhist art, and the conception and representation of ruins (fig. 7-8). ${ }^{24}$ These studies generally articulate two analytical models - "comparison" and "engagement" - to explore the changing relationship between different art traditions. Some historical cases have led to discoveries of historical engagements of people, ideas and forms. Others have led me to detect shared concepts as well as formal differences, both of which can serve as entryways to understand a particular regional art tradition in the global context.

1. James Elkins, Is Art History Global?, London, 2007; David Summers, Real Spaces: World Art History and the Rise of Western Modernism, London, 2003.

2. Summers, 2003, cited n. 1, pp. 45-50 and 56-58.

3. James Elkins, "Art History as a Global Discipline," in Elkins, 2007, cited n. 1, pp. 3-24.

4. David Carrier, A World Art History and its Objects, University Park (PA), 2008.

5. Monica Juneja, "Global Art History and the 'Burden of Representation'," in Hans Belting, Jakob Birken, Andrea Buddensieg, Peter Weibel, eds., Global Studies: Mapping Contemporary Art and Culture, Ostfildern, 2011, pp. 278-279.

6. Jeremy Tanner, "Portraits and Agency: A Comparative View," in Robin Osborne, Jeremy Tanner, eds., Art's Agency and Art History, Oxford, 2007, pp. 70-94; Kitty Zijlmans, Wilfried van Damme, "Art History in a Global Frame: World Art Studies," in Matthew Rampley et al., eds., Art History and Visual Studies in Europe: Transnational Discourses and National Frameworks, Leiden, 2012, pp. 217-229.

7. Elkins, 2007, cited n. 1, p. 19.

8. Craig Clunas, "The Toolkit and the Textbook," in Elkins, 2007, cited n. 1, pp. 270-285, esp. 280.

9. Christina Luke, Ulua Style Marble Vases, doctoral dissertation, Cornell University, Ithaca (NY), 2002.

10. Carolyn Dean, "The Trouble with (The Term) Art," in Art Journal, 65/2, 2006, pp. 24-32.
11. A group of prominent specialists in Precolumbian art history discuss the current state of their subdiscipline: Cecelia Klein, ed., Theory, Method, and the Future of Pre-Columbian Art History, conference notes published in Journal of Art Historiography, 7/CK-1, December 2012, published online: http://arthistoriography.files.wordpress. com/2012/12/klein.pdf. For examples of archaeologists, many working in the Americas, who do not express concern about using the word "art," see World Art, 3/1, 2013.

12. Thomas Pownall, "Observations Arising from an Enquiry into the Nature of the Vases Found on the Mosquito Shore in South America," in Archaeologia; Or, Miscellaneous Tracts, Relating to Antiquity, 5, 1779, pp. 318-324.

13. The case for this kind of historicism in art history was made most compellingly by Panofsky - and it is his greatest legacy to the field as well as (in its reductive form as sterile historicism) what the New Art History rebelled against. Panofsky himself was attempting to use cultural-historical context as a defense against the "roving arbitrariness" of the "violence of interpretation," as a model for all kinds of analysis (not only art-historical), which he identified in a key essay of 1932 with the work of Heidegger. See Erwin Panofsky, "On the Problem of Describing and Interpreting Works of Art" (1932), in Critical Inquiry, 38/3, Spring 2012, pp. 467-482, followed by Jaś Elsner, Katharina Lorenz, "The Genesis of Iconology," pp. 483-512. 
14. Esther Pasztory, "Pre-Columbian Art and World Art History," in Klein, 2012, cited n. 6, pp. 4-6; the paper was retitled after the conference where it was presented to include the allusion to "world art history."

15. Carolyn Dean, "The Inka Married the Earth: Integrated Outcrops and the Making of Place," in The Art Bulletin, 89/3, 2007, pp. 502-518. For an example of a discussion of the European concept of naturalism by archaeologists working on Palaeolithic art that explicitly engages with world art history works, see Oscar Moro Abadia, Manuel R. Gonzalez Morales, Eduardo Palacio Perez, "Naturalism' and the Interpretation of Cave Art," in World Art, 2/2, 2012, pp. 219-240.

16. Shelly Errington, "Globalizing Art History," in Elkins, 2007, cited n. 1, pp. 405-440.

17. Of course there have been attempts to look beyond Greco-Roman antiquity (although some like the work of Sir John Boardman remain decidedly Eurocentric). See e.g. Ann C. Gunter, Greek Art and the Orient, Cambridge, 2009 for a substantive effort to link the visual traditions of Greece and the Near East.

18. Rosemary A. Joyce, "Figurines, meaning, and meaning-making in early Mesoamerica," in Colin Renfrew, lain Morley, eds., Material Beginnings: A Global Prehistory of Figurative Representation, Cambridge, 2007, pp. 107-116. For related concerns expressed by Precolumbian art historians, see Dean, 2006, cited n. 10; Pasztory, 2012, cited n. 7; Elizabeth Boone, "What do You Say When There Are No Words?" in Klein, 2012, cited n. 11, pp. 13-18.
19. Compare the individual papers in World Art, 3/1, 2013, to George Lau, Veronica Sekules, Margit Thøfner, "Foreword: Why 'Art Makes Society'?", in World Art, 3/1, 2013, pp. 1-2; and "Afterword: Why 'Art Makes Society'?" in World Art, 3/1, pp. 163-168.

20. See, for example, Zainab Bahrani, "Assault and Abduction: the fate of the royal image in the ancient Near East," in Art History, 18/3, 1995, pp. 363-382.

21. Zainab Bahrani, The Graven Image: Representation in Babylonia and Assyria, Philadelphia, 2003.

22. There will be a series of publications from the University of Chicago Press. A starting point of this project might be the volume of RES edited by Wu Hung and myself on sarcophagi (which includes several Chinese and Greco-Roman papers, including one by Richard Neer) as well as a preColumbian piece: see the articles in Jaś Elsner, Wu Hung, Sarcophagi, RES, 61/2, 2012.

23. Ulrich Pfisterer, "Origins and Principles of World Art History: 1900 (and 2000)," in Kitty Zijlmans, Wilfried van Damme, eds, World Art Studies: Exploring Concepts and Approaches, Amsterdam, 2008, p. 76. See also, in the same volume, Marlite Halbertsma, "The Many Beginnings and the One End of World Art History," p. 91-105.

24. Wu Hung, Monumentality in Early Chinese Art and Architecture, Stanford, 1995; "Buddhist Elements in Early Chinese Art (2nd and 3rd century AD)," in Artibus Asiae, 47.3/4, 1986, pp. 263-347; A Story of Ruins: Presence and Absence in Chinese Art and Visual Culture, London/Princeton, 2012. 